PRZEGLĄD NAUK HISTORYCZNYCH 2018, R. XVII, NR 2

http://dx.doi.org/10.18778/1644-857X.17.02.09

C $|\mathbf{O}| \mathbf{P} \mid \mathbf{E}$

DROBNE PRACE I MATERIAEY

JM13714

Justyna GaŁuszka

UNIWERSYTET JAGIELLOŃSKI*

\title{
Jak Kraków witał arcyksiężniczkę? Uroczystości ślubne i koronacyjne Anny Habsburżanki i Zygmunta III Wazy w 1592 roku
}

U

roczystości państwowe i dworskie, a do takich na pewno możemy zaliczyć koronacje oraz śluby władców, mają dłu-

ga, jeszcze średniowieczna metrykę, a epoka nowożytna znacznie rozwinęła i udoskonaliła tę tradycję, nadając jej odpowiednia range wydarzenia kulturalnego, a także politycznego. Trudno nie zgodzić się ze stwierdzeniem Albrychta Stanisława Radziwiłła o istocie królewskiego małżeństwa: „Małżeństwo zwykłych ludzi powstaje ze skłonności dusz, królów zaś dla zadowolenia poddanych"1. Oprócz państwowych (a bardziej rodzinnych) funkcji tych wydarzeń (pogrzeby, koronacje, wesela, narodziny i chrzciny dzieci itd.), uroczystości te łączyła inna nadrzędna idea - chęć ukazania potęgi panującego oraz stabilności jego kraju. Społeczeństwo dzięki masowemu udziałowi w świętowaniu różnych wydarzeń mogło wyrazić swoje przywiązanie do dynastii i szacunek dla niej, co niewątpliwie scalało daną wspólnotę. Również okazały ceremoniał świecki i kościelny tych uroczystości nadawał im odpowiednią rangę, a służyła temu dodatkowo ich oprawa artystyczna.

Nie należy się zatem dziwić, że te barwne wydarzenia, które w Rzeczypospolitej nigdy nie osiagnęły rozmachu znanego chociażby $z$ cesarskiego dworu Habsburgów, zwracały uwagę współcze-

* Wydział Historyczny, Instytut Historii, Zakład Historii Polski Nowożytnej, e-mail: justynagaluszka92@gmail.com.

1 A.S. Radziwiłł, Pamiętnik o dziejach $w$ Polsce, t. I (1632-1636), oprac. i przekł. A. Przyboś, R. Żelewski, Warszawa 1980, s. 488. 
snych i budziły powszechna ciekawość. Stanowiły także wdzięczny temat do przekazywania ich przebiegu w różnorodnych relacjach, korespondencji uczestników, a także w okazjonalnych utworach literackich oraz pracach historycznych. W ostatnich latach badania nad królewskimi uroczystościami weselnymi przyniosły wiele nowych informacji ${ }^{2}$. Na uwagę szczególnie zasługuja publikacje Anny Filipczak-Kocur, Aleksandry Barwickiej-Makuli, Karoliny Targosz, Mieczysława Rokosza ${ }^{3}$ i Dominika Kadzika ${ }^{4}$, które podejmuja interesująca mnie problematykę we wszechstronny sposób. Warto przypomnieć również monumentalną, czterotomowa pracę Waltera Leitscha o życiu na dworze Zygmunta III $^{5}$. Wymienieni przeze mnie badacze nie tylko przedstawiali kulisy przygotowań politycznych do królewskiego małżeństwa, lecz także w kręgu ich zainteresowań znalazły się zagadnienia związane $z$ przebiegiem uroczystości czy finansowym aspektem wizyty zagranicznych goś-

${ }^{2}$ Literatura dotycząca uroczystości koronacyjnych i ślubnych jest obfita. Najistotniejsze publikacje $z$ punktu widzenia prezentowanego tu artykułu to: A. Barwicka-Makula, Stót królewski podczas uroczystości weselnych Zygmunta III Wazy i Anny Austriaczki w 1592 roku, [w:] Historia naturalna jedzenia: między antykiem a XIX wiekiem. Materiały $z$ międzynarodowej konferencji naukowej zorganizowanej przez Muzeum Historyczne Miasta Gdańska i Uniwersytet Gdański dla upamiętnienia 100-lecia otwarcia Muzeum Wnętrz Mieszczańskich w Domu Uphagena $w$ dniach 3-4 listopada 2011 roku, red. B. Możejko, Gdańsk 2012, s. 173-179; A. Falniowska-Gradowska, W. Leits ch, Gonitwa w maszkarach na Rynku Krakowskim (7 czerwca 1592 r.), „Rocznik Krakowski” 1985, t. LI, s. 31-56; A. Filipczak-Kocur, Wesele Zygmunta III i Anny w 1592 r. oraz koronacja królowej $w$ relacjach niemieckojęzycznych i polskich gazet ulotnych, [w:] Wesela, chrzciny i pogrzeby $w$ XVI-XVIII wieku. Kultura życia i śmierci, red. H. Suchojad, Warszawa 2001, s. 91-104; A. Szw ey kow s ka, Widowiska baletowe na dworze Zygmunta III (4 czerwca 1592, 13 oraz 18 grudnia 1605), „Muzyka” 1966, t. XI, nr 1 (40), s. 27-36; K. Targosz, Królewskie uroczystości weselne $w$ Krakowie i na Wawelu w 1512-1605, Kraków 2007; e ad e m, Oprawa artystyczno-ideowa wjazdów weselnych trzech sióstr Habsburżanek (Kraków 1592 i 1605, Florencja 1608), [w:] Theatrum ceremoniale na dworze ksiażat $i$ królów polskich. Materiały konferencji naukowej zorganizowanej przez Zamek Królewski na Wawelu i Instytut Historii Uniwersytetu Jagiellońskiego w dniach 23-25 marca 1998, red. M. Markiewicz, R. Skowron, Kraków 1999, s. 207-244.

${ }^{3}$ M. Rokosz, „Forum Polonorum et Via Regia”. Rynek krakowski i Droga Królewska scena wydarzen państwowych, religijnych, narodowych $i$ społecznych 1257-2010, [w:] Rynek krakowski odkryty na nowo, red. E. Firlet, Kraków 2014, s. 405-610.

${ }^{4}$ D. Kadzik, Utrzymanie królewskiej teściowej. Wizyta Marii Bawarskiej podczas wesela Zygmunta III Wazy z Anna Habsburg (23 maj- 16 czerwiec 1592 r.), Kraków 2017.

${ }^{5}$ W. Leits ch, Das Leben am Hof König Sigismunds III. von Polen. Bd. II, Kraków 2009, s. 1155-1258. 
ci w Krakowie. Podstawę źródłowa prezentowanego tu artykułu stanowia przede wszystkim opisy zamieszczone w nowożytnych kronikach: Marcina Bielskiego, kontynuowanej przez jego syna Joachima $^{6}$, który przedstawił te uroczystości, Pawła Piaseckiego ${ }^{7}$, Reinholda Heidensteina ${ }^{8}$, kronice nieznanego $z$ imienia i nazwiska mieszczanina krakowskiego ${ }^{9}$ oraz $\mathrm{w}$ relacjach rękopiśmiennych ${ }^{10}$. Szczególnie cennym rękopisem jest opis wjazdu oraz podarunków wręczanych parze królewskiej podczas uroczystości ślubnych. Jego edycja znajduje się w aneksie do artykułu ${ }^{11}$. Dzięki niej możemy prześledzić przebieg uroczystego wjazdu arcyksiężniczki i jej orszaku do Krakowa, królewskich zaślubin i koronacji oraz imprez organizowanych $z$ okazji tych wydarzeń, takich jak uczty, gonitwy etc.

Podejmowana przeze mnie problematyka jest istotna $z$ kilku powodów. Przede wszystkim uroczystości ślubne i koronacyjne zajmowały ważne miejsce $\mathrm{w}$ ceremoniale dworskim ${ }^{12}$. Poprzedzały je staranne przygotowania, dbano o ich szczególna oprawę, przez co wzbudzały zainteresowanie współczesnych. Relacje $z$ tych wydarzeń publikowano w licznych gazetach ulotnych m.in. w językach niemieckim, włoskim i czeskim ${ }^{13}$ - nie ma natomiast doniesień

${ }^{6}$ M. Biels ki, Kronika polska, wyd. K. Turowski, Warszawa 1829, s. 1670-1678.

7 P. Pias ecki, Kronika Pawła Piaseckiego biskupa przemyślskiego, przekł. J. Bartoszewicz, Kraków 1870, s. 192-193.

${ }^{8}$ R. Heidenstein, Dzieje Polski od śmierci Zygmunta Augusta do roku 1594: ksiag XII, przekł. M. Gliszczyński, oprac. i wyd. J. Byliński, W. Kaczorowski, Opole 2015, s. 602-605. Wzorował się na niemieckojęzycznym piśmie Königliche Heimfürung, przetłumaczonym przez Ambrożego Grabowskiego: Opisanie wspaniałego wjazdu Anny arcyksiężniczki austriackiej narzeczonej króla Zygmunta III oraz uroczystości jej zaślubienia i koronacyi roku 1592, [w:] A. Grabowski, Ojczyste spominki w pismach do dziejów dawnéj Polski, diaryusze, relacye, pamiętniki i.t.p. służyć mogące do objaśnienia dziejów krajowych tudzież listy historyczne do panowania królów Jana Kazimiérza i Michała Korybuta oraz listy Jana Sobieskiego marszałka i hetmana wielkiego koronnego, Kraków 1845, t. I, s. 36-39.

${ }^{9}$ Kronika mieszczanina krakowskiego z lat 1575-1595, wyd. H. Barycz, Kraków 1930, s. 106-132.

10 Wiazd krolowey polskiey zony Iszey Zygmunta III do Krakowa porzadnie spisany $z$ podarunki, ktore dawano na weselu krola JMSCI 1595! Roku, Biblioteka Kórnicka PAN [dalej: BK PAN], rkps 309; Biblioteka Książąt Czartoryskich w Krakowie [dalej: BCz] 197 II, 212 I, 405 I, 456 I, 1977 II [starodruki]; Biblioteka Jagiellońska w Krakowie, CIM QU. 5320 [starodruk].

11 Wiazd krolowey polskiey..., BK PAN, rkps 309.

12 B. Fabiani, Na dworze Wazów w Warszawie, Warszawa 1988, s. 102.

13 Katalog gazet ulotnych o zaślubinach arcyksiężniczki i króla: K. Z aw a d z ki, Gazety ulotne polskie i Polski dotyczace XVI-XVIII wieku. Bibliografia. T. 1, 1514 1661, Wrocław 1977, s. 59-62. 
o tych wydarzeniach wśród ówczesnych polskich efemeryd prasowych $^{14}$. Niewątpliwie intencją młodego króla była promocja państwa polsko-litewskiego i dynastii Wazów na arenie międzynarodowej, stąd wspomniane wyżej doniesienia w językach obcych. Zaślubiny i koronacja były nie tylko wydarzeniami ważnymi $z$ punktu widzenia państwa i dynastii, lecz także ze względu na ich bogatą oprawę artystyczna, liczne imprezy kulturalne, towarzyszące i uświetniajacce wesele, trwające zazwyczaj kilka dni.

Małżeństwa, zwłaszcza władców, miały przede wszystkim charakter polityczny. Wazowie, jako młoda dynastia, niemająca jeszcze ustalonej pozycji w Europie, stanęli przed koniecznością zbudowania prestiżu przez odpowiednia politykę matrymonialną. W epoce nowożytnej trudno wyobrazić sobie lepsza partię niż Habsburgowie - była to bowiem najbardziej liczacca się dynastia Starego Kontynentu. Mariaż z Domem Habsburskim dodawał zatem prestiżu polsko-szwedzkiej dynastii. Pierwsza żona Zygmunta III, arcyksiężniczka Anna, była córka Marii Anny Bawarskiej (1551-1608) i Karola Styryjskiego (1540-1590), stryjeczna siostra cesarzy Rudolfa II i Macieja I Habsburgów, rodzoną siostra późniejszego cesarza, Ferdynanda II (od 1619 r.) i królowej hiszpańskiej (od 1599 r.) Małgorzaty, żony Filipa III Habsburga oraz Marii Magdaleny Habsburg, żony księcia Toskanii od 1608 r. ${ }^{15}$ Matkę arcyksiężniczki można określić jako architektkę mariażu córki. Wywodziła się z rodu Wittelsbachów. Była najstarszą córką Albrechta V (1528-1578) i Anny Habsburg (1528-1590). Maria Bawarska i Karol Styryjski zawarli związek małżeński w 1571 r., doczekali się 15 dzieci: sześciu synów i dziewięciu córek. Maria Anna starała się wpływać na politykę w swojej nowej ojczyźnie. Była gorliwą katoliczką, wspierającą jezuitów i surowo przestrzegająca zasad wiary. W tym duchu wychowała swoje potomstwo. Po śmierci męża nie osiadła w Judenburgu, który został jej przydzielony jako wdowie, lecz pozostała w Grazu ${ }^{16}$.

${ }^{14}$ K. Zawad zki, Poczatki prasy polskiej. Gazety ulotne i seryjne XVI-XVIII wieku, Warszawa 2002, s. 92.

${ }^{15}$ K. Le pszy, Anna Austriaczka (1573-1598), [w:] Polski słownik biograficzny [dalej: $P S B$ ], t. I, Kraków 1935, s. 132-133; A. Barwicka-Makula, Anna Austriaczka (16 sierpnia 1573 - 10 lutego 1598), [w:] Poczet władczyń Polski, red. B. Czwojdrak, Kraków 2017, s. 297-301.

16 Szerzej o życiu i działalności Marii Anny Bawarskiej: K. Keller, Erzherzogin Maria von Innerösterreich (1551-1608). Zwischen Habsburg und Wittelsbach, Wien-Köln-Weimar 2012. 
Choć przyszła królowa - arcyksiężniczka Anna - nie odznaczała się uroda, to jednak pewne braki w wyglądzie rekompensowały koligacje rodzinne, co czyniło arcyksiężniczkę dobra partią ${ }^{17}$. Starania o jej rękę dla królewicza szwedzkiego Zygmunta Wazy toczyły się od 1580 r. pod opieka Stolicy Apostolskiej, a zatem na długo przed elekcją syna króla Szwecji Jana III Wazy i Katarzyny Jagiellonki. Początkowo przeszkodami były wiek, konieczność przejścia na protestantyzm Zygmunta po objęciu tronu w Sztokholmie, ale największym problemem okazała się przegrana Domu Habsburskiego w rywalizacji o koronę po śmierci Stefana Batorego w 1586 r. Plany matrymonialne nowego króla spotkały się w Rzeczypospolitej polsko-litewskiej $z$ niechęcią senatorów, którym projekt tego związku, rozumianego jako element sojuszu $z$ Habsburgami, nie przypadł do gustu. Kwestia monarszego mariażu była wielokrotnie poruszana podczas prób unormowania stosunków między Rzeczapospolitą a Cesarstwem, których ukoronowaniem był traktat bytomsko-będziński z 9 marca 1589 r. ${ }^{18}$ Jak wykazały badania Kazimierza Lepszego $^{19}$ i najnowsze opracowanie Aleksandry Barwickiej-Makuli, projekt małżeństwa przez wiele miesięcy pozostawał w cieniu wielkiej polityki: niedawnego militarnego konfliktu o tron polski, działań stronnictwa austriackiego w Rzeczypospolitej czy wreszcie niegasnących pretensji Habsburgów do panowania nad Wisłą ${ }^{20}$. Senat w 1589 r. uchwalił, że „przyszła królowa powinna pochodzić $z$ rodziny znakomitej i katolickiej" ${ }^{21}$. Senatorowie chcieli wykorzystać plan mariażu $z$ Domem Habsburskim do pacyfikacji zarówno kontaktów z cesarzem, jak i stosunków wewnętrznych w Rzeczypospolitej. Zygmunt III odkładał jednak ostateczna decyzję o mał-

17 O wizerunkach arcyksiężniczki Anny m.in. A. Bochnak, Portrety Zygmunta III i Anny Austriaczki w Muzeum Uniwersytetu Jagiellońskiego, „Prace Komisji Historii Sztuki Polskiej Akademii Umiejętności” [Kraków] 1946, t. VIII, s. 327-335; J. Ru s zczy c, Portrety Zygmunta III i jego rodziny, „Rocznik Muzeum Narodowego w Warszawie" [Warszawa] 1969, t. XIII, cz. 1, s. 151-264.

18 Szerzej na temat okoliczności zawarcia układu oraz procesu jego ratyfikacji: H. W is n e r, Dyplomacja polska w latach 1572-1648, [w:] Historia dyplomacji polskiej, t. II (1572-1795), red. Z. Wójcik, Warszawa 1982, s. 26-29.

${ }_{19}$ K. Le p s zy, Rzeczpospolita Polska $w$ dobie sejmu inkwizycyjnego (1589-1592), Kraków 1939.

20 A. Barwicka-Makula, Od wrogości do przyjaźni. Habsburgowie austriaccy wobec Polski $w$ latach 1587-1592, praca doktorska pod kierunkiem dr. hab. R. Skowrona, Katowice 2013, https://fbc.pionier.net.pl/details /nn8gSZ1 (dostęp: 18 XII 2017).

${ }^{21}$ K. Lepszy, op. cit., s. 43. 
żeństwie do czasu spotkania $z$ ojcem, Janem III Wazą w Rewlu we wrześniu 1589 r. Gdy Maksymilian odmówił zaprzysiężenia traktatu bytomsko-będzińskiego, wydawało się, że rokowania dotyczace mariażu zakończą się fiaskiem, gdyż postawa arcyksięcia wywołała opór ze strony polskich i litewskich senatorów - dotychczasowych zwolenników złączenia Domu Habsburskiego z Rzeczapospolitą ${ }^{22}$. Śmierć ojca arcyksiężniczki, Karola Styryjskiego w lipcu 1590 r. dodatkowo utrudniała pomyślne rozwiazanie tej kwestii.

Pertraktacje na temat małżeństwa wznowiono na przełomie 1590 i 1591 r. z inicjatywy cesarza Rudolfa II, który nakazał swoim posłom - biskupowi wrocławskiemu Andreasowi Jerinowi (15401596) i Richardowi Streinowi (1538-1600) - prowadzenie rozmów z młodym Wazą ${ }^{23}$. Wtedy też do zabiegów o rękę arcyksiężniczki włączyła się dyplomacja papieska - proszono zarówno marszałka wielkiego koronnego Andrzeja Opalińskiego, jak i nuncjusza papieskiego Hannibala $z$ Kapui o szczególne zaangażowanie w sprawę małżeństwa Zygmunta III $z$ kobietą religijna i pobożną ${ }^{24}$. Potencjalni narzeczeni wymienili się portretami oraz listami. Opozycja w państwie polsko-litewskim, $z$ kanclerzem Zamoyskim i hetmanem polnym koronnym Stanisławem Żółkiewskim na czele, groziła, że nie dopuści do wjazdu arcyksiężniczki do Rzeczypospolitej. Kulisy sporu między władca a dostojnikami zdradza pełen goryczy i wyrzutów list hetmana i kanclerza wielkiego koronnego Jana Zamoyskiego $^{25}$. Mimo tych przeciwności król podjął decyzję o małżeństwie $z$ arcyksiężniczką. Swoją radość w liście do przyszłego zięcia wyraziła matka arcyksiężniczki, Maria Bawarska, informując jednocześnie o planowanym wyjeździe do Rzeczypospolitej ${ }^{26}$. Zawarcie przez władcę małżeństwa poprzedzały rokowania dyplomatyczne, ustalanie warunków kontraktu ślubnego i wysokości posagu.

Wiosną następnego roku do Rudolfa II zostało wyprawione poselstwo złożone $z$ biskupa kujawskiego Hieronima Rozrażewskiego (ok. 1546-1600) ${ }^{27}$ i marszałka wielkiego litewskiego Albrychta

22 Ibidem, s. 95.

23 A. Barwicka-Makula, Od wrogości..., s. 342.

${ }^{24}$ Klemens VIII do Andrzeja Opalińskiego, Rzym 20 I 1591, BK PAN, rkps 245, k. 241; tenże do Hannibala z Kapui, Rzym [brak daty], ibidem, k. 241-241v. Notabene wówczas papieżem był jeszcze Grzegorz XIV (1535-1591), który zmarł 16 X w Rzymie. Jego następca był Klemens VIII (1536-1605), papież od 30 I 1592 r.

${ }_{25}$ Jan Zamoyski do Zygmunta III, Zamość 27 I 1591, BCz, rkps 351, s. 17-19.

${ }^{26}$ Maria Bawarska do Zygmunta III, Graz 1592, BK PAN, rkps 245, k. 245v-246.

27 A. Barwicka, Hieronim Rozdrażewski (Rozrażewski) (ok. 1546-1600), [w:] Polscy dyplomaci w Wiedniu 1515-2015, red. B. Dybaś, Wiedeń 2015, s. 44-45. 
Radziwiłła (1558-1592) ${ }^{28}$. W Wiedniu dołączył do nich kardynał Jerzy Radziwiłł (1556-1610), który występował jako przedstawiciel papieża ${ }^{29}$. W dniu 17 kwietnia 1592 r. w Pradze została podpisana umowa małżeńska, a posłowie udali się do Wiednia, gdzie oczekiwała ich królewska narzeczona $z$ matka, Maria, i stryjecznymi braćmi, arcyksiążętami Ernestem i Maciejem (późniejszym cesarzem Maciejem I Habsburgiem) ${ }^{30}$. Po zawarciu ślubu per procura w Wiedniu (3 maja 1592 r.), którego udzielał kardynał Radziwiłł, a marszałek wielki zastępował Zygmunta III, odbyła się uczta i tańce. Brali w nich udział matka arcyksiężniczki, Maria Bawarska, oraz Ernest i Maciej ${ }^{31}$. Franciszek Siarczyński przytacza ciekawy opis zwyczaju towarzyszącego zaślubinom per procura. Ślub należało dopełnić przez akt tzw. pokładzin: „jeden $z$ posłów polskich pierwszej po ślubie nocy, cały w zbroję odziany obok królowej się położył, podług obrządku [...] jaki królowie polscy w takowym przypadku zachowywać zwykli”32.

Po ślubie Anna wyruszyła $z$ orszakiem, liczacym 431 osób ${ }^{33}$, do nowej ojczyzny. Towarzyszyła jej matka, posłowie cesarscy Georg IV Ludwig landgraf von Leuchtenberg oraz biskup wrocławski Andreas Jerin, choć ten ostatni dołączył do pochodu dopiero w Pszczynie, i wysłannicy Zygmunta III. Wzorem poprzednich podróży kierowano się do Krakowa. Granicę Rzeczypospolitej przekroczono 14 maja. Naprzeciw arcyksiężniczki wyjechali wpierw senatorowie ze swoimi pocztami, by powitać ją w imieniu małżonka w Balicach i eskortować do Łobzowa, gdzie oczekiwał na nią Zygmunt III. Wśród witających przyszłą królową był Wawrzyniec Goślicki, ówczesny biskup przemyski. W świetle opisu mieszczanina krakowskiego orszaki zarówno arcyksiężniczki, jak i władcy były bardzo okazałe i wspaniale się prezentowały. Na powitanie przyszłej władczyni wyszli również przedstawiciele niższych stanów: mieszczaństwo i pospólstwo Krakowa, Kazimierza oraz Kleparza. Król przebywał

${ }^{28}$ A. Kalinows ka, Albrycht Radziwitk (1558-1592), [w:] ibidem, s. 52-53.

${ }^{29}$ Król Zygmunt III do cesarza Rudolfa II, Kraków 19 VIII 1591, [w:] The house of Vasa and the house of Austria: correspondence from the years 1587 to 1668. Pt. 1, The times of Sigismund III, 1587-1632. Vol. 1, ed. R. Skowron, Katowice 2016, s. 256-258.

30 Ibidem.

31 „Austriacka” część uroczystości weselnych została przedstawiona w pracy: K. Vocelka, Habsburgische Hochzeiten 1550-1600. Kulturgeschichtliche Studien zum manieristischen Repräsentationsfest, Wien 1976, s. 120-124.

${ }^{32}$ F. Siarczyński, op. cit., s. 380-381.

${ }^{33}$ K. Vocelka, op. cit., s. 120. 
w Łobzowie, gdzie rozłożono cztery ozdobne namioty, urządzone na modłę turecka, zgodnie $z$ opisem autora kroniki, bardzo okazałe. Zygmuntowi III towarzyszyły „stara królowa” Anna Jagiellonka oraz siostra, królewna szwedzka Anna Wazówna. Księżniczkę w imieniu króla witał Jan Tarnowski, natomiast odpowiedział mu Andreas Jerin. Po powitaniu odbył się wspólny wjazd do Krakowa w ustalonym porzadku: najpierw piechota miejska, piechota królewska, poczty konne, następnie konno Zygmunt III w otoczeniu posłów cesarskich, za nimi w karocy arcyksiężniczka Anna ze swoją matką Marią. Potem następowały królowa Anna Jagiellonka oraz królewna Anna, żony dostojników, fraucymery arcyksiężniczki i polski. Cały orszak liczył 4900 konnych, 5700 pieszych oraz 262 osoby jadace w karetach. W orszaku można było wypatrzeć nawet dwa wielbłądy, które prowadzone były przez Turków. Słychać było różne języki: „jedni po włosku, drudzy po murzyńsku, drudzy po arabsku, drudzy po turecku"34, jak opisywał krakowski mieszczanin. Komentował on również wygląd samych Polaków, którzy nie szczędzili kosztów i nakładów, by godnie się prezentować podczas tej uroczystości.

Po raz pierwszy w 1592 r. wzniesiono bramy triumfalne na powitanie nowej pani. Na trasie pochodu stanęło pięć takich budowli: w pobliżu kościoła św. Floriana, za Bramą Floriańska, przy styku ulicy Floriańskiej z Rynkiem, na ulicy Grodzkiej oraz ostatnia przed samym Wawelem ${ }^{35}$. Można pokusić się o stwierdzenie, że wznoszeniem bram triumfalnych nawiązywano do antycznego zwyczaju zwieńczania takimi konstrukcjami sukcesów militarnych ${ }^{36}$. Największą sensację wzbudził jednak poddany Stanisława Stadnickiego, który wspiął się na szczyt wieży mariackiej z biało-czerwonym proporcem, na którym namalowany był wielki biały orzeł ${ }^{37}$. Ślub i koronacja nowej monarchini, spodziewane $z$ tego tytułu korzyści polityczne, były odczytywane jako jeden $z$ sukcesów monarchy, choć ówczesna sytuacja polityczna w kraju była niesprzyjająca ${ }^{38}$. Zadbano o ich artystyczna oprawę: przejazdowi towarzyszyli muzy-

${ }^{34}$ Kronika..., s. 107.

35 Ibidem, s. 112; M. Rożek, Uroczystości w barokowym Krakowie, Kraków 1976, s. 33-34.

${ }^{36}$ J.A. Chrościcki, Barokowa architektura okazjonalna, [w:] Wiek XVII. Kontrreformacja. Barok, red. J. Pelc, Wrocław 1970, s. 232.

${ }_{37}$ M. Rożek, Polskie koronacje i korony, Kraków 1987, s. 64.

${ }^{38}$ K. Targos z, Oprawa artystyczno-ideowa wjazdów weselnych trzech sióstr Habsburżanek (Kraków 1592 i 1605, Florencja 1608), [w:] Theatrum ceremoniale..., s. 213. 
cy, śpiewano pieśni, odnowiono również sam zamek oraz kamienice na trasie przejazdu ${ }^{39}$. Paweł Piasecki czy wspomniany mieszczanin krakowski podkreślaja, że nie żałowano środków na najdroższe tkaniny, którymi ozdobiono kamienice, a w nocy oświetlono je latarniami ze świecami. Uroczysty wjazd trwał od godziny 15.00 do $18.30^{40}$. Po przybyciu na Wzgórze Wawelskie udano się do katedry, gdzie arcyksiężniczkę powitała kapituła krakowska i odśpiewano uroczyste Te Deum laudamus. Następnie król odprowadził Annę z matką do pokoi na Kurzej Stopce. Rozlegały się strzały $z$ armat, zarówno na Zamku, jak i w mieście.

Dalsza część uroczystości nastapiła w niedzielę 31 maja 1592 r. (wcześniej odbyła się procesja Bożego Ciała, której księżniczka z matka przyglądała się z Zamku) ${ }^{41}$. Na konfirmację małżeństwa i koronację Anny przybyła szlachta polska oraz litewska, służba i widzowie musieli pozostać poza Zamkiem. Również orszak weselny został odpowiednio sformowany: króla odziano w kapę i albę, na głowie miał koronę, w rękach pozostałe insygnia władzy: jabłko i berło. Zygmunt III kroczył w asyście biskupa krakowskiego Jerzego Radziwiłła oraz biskupa płockiego Wojciecha Baranowskiego. Za nimi postępowała arcyksiężniczka w otoczeniu arcybiskupa lwowskiego Jana Dymitra Solikowskiego oraz biskupa łuckiego Bernarda Maciejowskiego. Przed przyszła królowa niesiono koronę, berło i jabłko ${ }^{42}$. Następnie kroczyła Anna Wazówna $z$ arcyksiężną Marią, które prowadzone były przez posłów cesarskich. W takim porządku orszak udał się do katedry wawelskiej, gdzie odbyła się uroczysta msza święta, obrzęd zaślubin (dokonał go kardynał Jerzy Radziwiłł) oraz koronacja arcyksiężniczki. Koronatorem był biskup kujawski Hieronim Rozrażewski, w zastępstwie wymawiajacego się rzekoma choroba prymasa Stanisława Karnkowskiego, co wywołało opór ze strony Solikowskiego ${ }^{43}$. Choć lektura relacji $z$ tych wydarzeń może sugerować, że konfirmacja małżeństwa i ślub stanowiły jedność, były to w rzeczywistości dwa akty ${ }^{44}$.

${ }^{39}$ A. Leszczyńska, O muzyce $w$ obrzędach koronacyjnych królów polskich, „Polski Rocznik Muzykologiczny” 2015, t. XIII, s. 85-86.

${ }^{40}$ Kronika..., s. 111-113.

${ }^{41}$ Ibidem, s. 114.

${ }^{42}$ S. Windakiewicz, Dzieje Wawelu, Kraków 1925, s. 116.

${ }^{43}$ R. Heidenstein, op. cit., s. 604. Jak stwierdza A. Barwicka-Makula, choroba Karnkowskiego była dyplomatycznym sposobem usprawiedliwienia nieobecności podczas koronacji. Por. eade m, Od wrogości..., s. 356.

${ }^{44}$ S. Kutrzeba, Koronacje królów i królowych w Polsce, Warszawa 1918, s. $20-22$. 
Po tych uroczystościach udano się do Zamku. Zygmunt III przebrał się ze stroju koronacyjnego, natomiast młoda królowa pozostała w swym stroju i z korona na głowie uczestniczyła w uczcie weselnej, która trwała do godziny $22.00^{45}$. Uroczysty obiad został stosunkowo dokładnie omówiony w źródłach: opisano zarówno produkty, $z$ których przygotowano dania, jak i dekorację sali, liczbę uczestników, podkreślono nieobecność chorej Anny Jagiellonki ${ }^{46}$. Uroczystości weselne trwały do 7 czerwca. Odbywały się w tym czasie zarówno uczty, tańce, jak i widowiska kostiumowo-baletowe, teatralne oraz gonitwa rycerska $z$ udziałem samego kró$1 \mathrm{a}^{47}$. Zdaniem Stanisława Windakiewicza intencja monarchy było przyćmienie uroczystości weselnych Gryzeldy Batorówny i Jana Zamoyskiego z 12 czerwca 1583 r. $^{48}$

$Z$ okazji ślubu powstały również utwory literackie, m.in. Epithalamium na wesele Zygmunta III $i$ arcyksiężniczki J.M. rakuskiej Anny pióra Andrzeja Zbylitowskiego oraz dzieło Szymona Szymonowica, również zatytułowane Epithalamium. Podczas uważnej lektury można rozpoznać, że Szymonowic był o wiele bardziej ostrożny w pochwałach niż Zbylitowski, który szeroko wychwalał urodę i cnoty młodej królowej. Szymonowic przede wszystkim błagał Annę, aby wsłuchiwała się w głosy obywateli Rzeczypospolitej mordowanych przez Tatarów na Podolu ${ }^{49}$. Do grona autorów utworów okolicznościowych powstałych po zawarciu związku małżeńskiego przez arcyksiężniczkę i polskiego króla należy dodać Joachima Bielskiego $^{50}$ i Stanisława Sokołowskiego ${ }^{51}$. Pozostałe utwory umieścił w swej Bibliografii Karol Estreicher ${ }^{52}$.

45 Kronika..., s. 119.

46 A. Barwicka-Makula, Stół królewski..., s. 177-178.

47 A. Falniowska-Gradowska, W. Leitsch, op. cit., s. 31-56.

${ }^{48}$ S. Windakiewicz, op. cit., s. 117. O zaślubinach J. Zamoyskiego m.in. E. Dubas-Urwanowicz, Wesele Jana Zamoyskiego z Gryzelda Batorówna, „Białostockie Teki Historyczne” 2011, t. IX, s. 237-251.

${ }^{49}$ E. Rudzki, Polskie królowe. Żony królów elekcyjnych II, Warszawa 1987, s. 53. Szerzej: J. Now ak-Dłużew ski, Okolicznościowa poezja polityczna $w$ Polsce. Zygmunt III, Warszawa 1971, s. 334-336.

50 Przedruki w: Ioachimi Bilscii Carmina Latina. Nuncprimum in unumvolumencollecta, ed. T. Bieńkowski, Warszawa 1962, s. 113-116; oraz M. Malicki, Joachima Bielskiego nieznane polskie „Epithalamion” na ślub Zygmunta III $i$ Anny Austriaczki, „Biuletyn Biblioteki Jagiellońskiej” [Kraków] 1994, t. XLIV, nr 1-2, s. $119-129$.

${ }^{51}$ L. Grzebień, Sokołowski (Socolovius) Stanisław h. Gozdawa (1537-1593), [w:] PSB, t. XL, Warszawa-Kraków 2000-2001, s. 183-189.

${ }^{52}$ K. Estreicher, Bibliografia polska, t. XII, Kraków 1891, s. 162-163. 
Relacje poświęcone uroczystościom zaślubin Anny i Zygmunta oraz koronacji nowej władczyni pozwalaja na wierne odtworzenie przebiegu tych wydarzeń. Sam akt koronacji możemy porównywać $z$ podobnymi uroczystościami królów polskich, natomiast osobna sprawa pozostaje oprawa artystyczna wjazdów i zaślubin monarszych. Możliwe jest jej poznanie dzięki licznym opisom, które pozwalają na zrekonstruowanie tej szczególnej architektury okazjonalnej, w swym założeniu $z$ góry skazanej na likwidację ${ }^{53}$. Kunsztowne tkaniny, herby, monogramy, obrazy, elementy oświetleniowe, elementy wykonane $z$ drewna, gipsu, masy papierowej czy płótna, wreszcie bramy triumfalne - to wszystko składało się na złożona i bogatą kompozycję, uświetniająca moment powitania każdej królowej w nowej ojczyźnie.

Uroczystości, które poddałam analizie w prezentowanym tu tekście, sa wyjątkowe także $z$ innych powodów. Przede wszystkim były to przedostatnie uroczystości powitalne i weselne, które w całości odbywały się w Krakowie (ostatnie miały miejsce w 1605 r. z okazji mariażu arcyksiężniczki Konstancji i Zygmunta III). Imprezy krakowskie w 1592 r. były długie - trwały około dwa tygodnie, niektóre elementy programu (bankiety, bale, balety, występy teatralne, turnieje i maskarady) przeplatały się z uroczystościami kościelnymi i państwowymi. Zamykały one w pewnym sensie epokę renesansu w Rzeczypospolitej ${ }^{54}$. Dopiero po kilkunastu dniach goście obdarowani przez króla rozjeżdżali się i życie na dworze królewskim wracało do normy. Wydarzenia te, dzięki relacjom w językach niemieckim, włoskim czy czeskim ${ }^{55}$, zostały rozpowszechnione wśród zachodnich odbiorców. O kilkunastodniowym programie kulturalno-artystycznym, ukazujacym świetność dworu polsko-litewskiego, dowiedzieli się mieszkańcy państw europejskich. Odegrały one istotna rolę w kształtowaniu w Europie opinii publicznej o młodym władcy Rzeczypospolitej, jego otoczeniu i przyjaźni z Habsburgami, której symbolem było zawarte w 1592 r. małżeństwo. Podziw budzi również rozmach, $z$ jakim zorganizowano owe wydarzenia, biorąc pod uwagę trudną sytuację wewnętrzną i zewnętrzna kraju oraz niełatwy początek panowania pierwszego władcy $z$ dynastii Wazów (rozdwojona elekcja, konieczność rywalizacji z przed-

${ }^{53} \mathrm{~K}$. Targos z, Królewskie uroczystości weselne $w$ Krakowie $i$ na Wawelu w 1512-1605, Kraków 2007, s. 16.

54 Ibidem, s. 5.

${ }^{55}$ K. Zawadzki, Gazety ulotne..., nr 232-241. 
stawicielem najważniejszego rodu panującego na kontynencie europejskim, opozycja wewnętrzna etc.).

Wjazd pierwszej żony Zygmunta III możemy analizować także pod katem ikonograficznym, gdyż zachowały się dwa przedstawienia artystyczne tych wydarzeń. Uroczyste powitanie arcyksiężniczki Anny zostało przedstawiony na rycinie, dołączonej do niemieckiej relacji Königliche Heimführung ${ }^{56}$. Wyeksponowano na niej moment spotkania pary królewskiej i dojazd do murów miejskich głównych bohaterów tego wydarzenia. Widoczne są również liczne zbrojne hufce oraz zgromadzeni ludzie ${ }^{57}$. Drugie $z$ przedstawień, przechowywane w Bibliotece Ksiąząt Czartoryskich w Krakowie, również prezentuje wjazd arcyksiężniczki Anny do Krakowa ${ }^{58}$. Został wykonany także medal okolicznościowy $z$ popiersiami Zygmunta III i jego świeżo poślubionej małżonki ${ }^{59}$. Osobnego omówienia wymaga obrzęd koronacji, który jednak niczym nie odbiegał od rytuału ustalonego za panowania Zygmunta I Starego, zastosowanego podczas uroczystości w latach 1512 i 1518 odpowiednio z Barbarą Zápolyą (zm. 1515) i Boną Sforzą (1494-1557), wzbogacanego licznymi wydarzeniami towarzyszacymi: przedstawienia teatralne, uczty etc. Obrzęd koronacji następował podczas mszy świętej. W czasie śpiewania litanii do Wszystkich Świętych nowa królowa leżała krzyżem, następnie namaszczano jej prawą rękę i plecy między łopatkami. Potem biskup koronator zdejmował $z$ głowy władczyni wieniec i wkładał koronę, do rąk zaś monarchini otrzymywała berło oraz jabłko i była odprowadzana do tronu, przygotowanego obok małżonka ${ }^{60}$.

Dla Zygmunta III mariaż $z$ domem Habsburskim okazał się pomyślny, co w dziejach królewskich małżeństw wcale nie było reguła. Władca kochał swoją żonę, żył z nią w zgodzie, ona zaś obdarzyła go potomstwem, które przedłużyło dalsze panowanie dynastii Wazów w Rzeczypospolitej. Również warte podkreślenia są uroczystości, które z okazji zaślubin odbyły się w Krakowie. Wzorowane były na podobnych imprezach organizowanych na dworach

${ }^{56}$ Muzeum Historyczne Miasta Krakowa, nr inw. MHK-909/VIII.

${ }^{57}$ J. Pirożyński, Krakowskie uroczystości państwowe $i$ dworskie $w$ drugiej połowie XVI wieku $w$ świetle ówczesnych prototypów prasowych, [w:] Theatrum ceremoniale..., s. 197.

${ }^{58} \mathrm{BCz} 405 \mathrm{I}$.

59 Muzeum Narodowe w Krakowie, nr inw. MNK VII-Md-186.

${ }^{60}$ M. Rożek, Polskie..., s. 57-58. 
zachodnioeuropejskich i tym standardom odpowiadały. Zwłaszcza wesele oraz koronacja Anny Austriaczki były dużym wydarzeniem nie tylko politycznym, lecz także kulturalnym i społecznym.

Edycja źródłowa została przygotowana zgodnie $z$ instrukcja wydawniczą dla źródeł historycznych autorstwa Kazimierza Lepszego $^{61}$. Biorac jednak pod uwage to, że zasady te nie do końca odpowiadają współczesnym wymogom krytycznego edytorstwa, starałam się wprowadzić zmiany, które $z$ jednej strony zachowałyby styl i wymowę dawnej polszczyzny, a $z$ drugiej, stały się jasne i zrozumiałe dla każdego czytelnika, w tym niebędacego specjalistą w dziedzinie historii czy historii języka polskiego. Zdecydowałam się na rozwinięcie skrótów tytulaturowych w formie wersalikowych zbitek: „Wmć" = "Waszmość", „JP” = "Jaśnie Pan” oraz innych skrótów w tekście. Przyjęłam zasadę pełnego tłumaczenia zwrotów łacińskich, zapisanych w edycji kursywa, w nawiasach kwadratowych "[]", co jest obecnie standardowym wymogiem w edycji tekstów staropolskich. W przypadku niemożności odczytania fragmentu tekstu fakt ten zaznaczyłam symbolem „[...]”. Uwspółcześniłam interpunkcję oraz poprawiłam błędy językowe, które nadały wyrazom ich współczesne brzmienie, np. zamiast „prętko” - „prędko”. Zdecydowałam się jednak na zachowanie oryginalnego brzmienia nazw własnych i geograficznych, stąd też Czytelnik znajdzie w tekście takie określenia, jak: „Hanszpach” (margrabia Ansbach) etc. Ta sama uwaga dotyczy urody i specyfiki szesnastowiecznego języka polskiego, stąd też zachowałam słowa zgodnie $z$ ich ówczesną wymową: „okazyja”, „będziem”, „wjachaniu”, „wszystkę”, "naszemi”, „Polszcze”, „powiedamy”, „przyjachał” etc.

${ }^{61} \mathrm{~K}$. Lepszy, Instrukcja wydawnicza dla źródeł historycznych od XVI $w$. do pot. XIX w., Warszawa 1953. 


\section{Tekst źródłowy}

Or.: Biblioteka Kórnicka PAN, rkps 309, k. 1-9.

[k. 1]

aWjazd Królowej Polskiej żony 1-szej Zygmunta III do Krakowa porządnie spisany $z$ podarunki, które dawano na weselu Króla Jmci 1595 roku $^{62}$ a $^{a}$

\section{Anno 1595}

\section{A naprzód}

Po wjechaniu Jego Mości do Krakowa die [dnia] 22. Aprilis [kwietnia].

Wiedząc Król Jegomość o przyjeździe Arcyksiężny Jej Mości, wysłał $\mathrm{k}<$ siędza> Baranowskiego biskupa płockiego ${ }^{63}$ i Pana Malagowskiego $^{64}$ die [dnia] 11. Maii [maja], która oni potkali za Freysztatem ${ }^{65}$ mila.

Dnia 15. Mai [maja] potem Jego Mość Pan marszałek litewski ${ }^{66}$, zostawiwszy biskupa kujawskiego ${ }^{67}$ przy niej na granicy [k. 1v], sam naprzód do Krakowa przyjachał, częścią oznajmując Król Jego Mość o przybyciu Królowej Jej Mości, częścią dla złego zdrowia małżonki swej68. W którem też i sam był, mając kwarantannę. Potem die 23. Maii [maja] znowu przeciwko Arcyksiężnie Jej Mości potykając, wyjachał. Tegoż die [dnia] ksiądz biskup kujawski do Krakowa wjechał, zostawiwszy Arcyksiężnę w Freysztacie.

62 Oczywista pomyłka pisarska: zaślubiny Anny Habsburżanki i Zygmunta III Wazy odbyły się w 1592 r.

${ }^{63}$ Wojciech Baranowski (1548-1615) - biskup płocki w latach 1591-1608.

${ }^{64}$ Prawdopodobnie chodzi o Sebastiana Lubomirskiego (ok. 1546-1613) - kasztelana małogoskiego.

${ }^{65}$ Frysztat - miasto w dawnym Księstwie Cieszyńskim należącym do Królestwa Czech. W drugiej połowie XVI w. utworzone zostało tzw. Frysztackie Państwo Stanowe, składajace się $z$ miasta i kilkunastu wsi.

${ }^{66}$ Albrycht Radziwiłł (1558-1592) - marszałek wielki litewski w latach 15861592.

67 Hieronim Rozrażewski (1546-1600) - biskup kujawski w latach 1582-1600.

${ }^{68}$ Maryna z Makowic Myszczanka (1563-1600) - córka kasztelana wołyńskiego Michała Myszki. 
Dnia 24. Maii [maja] w niedzielę ksiądz biskup krakowski Radziwiłł ${ }^{69}$ posłem od Papieża ${ }^{70} z$ winszowaniem Jego Królewskiej Mości do Krakowa wjachał, którego wszyscy senatorowie natenczas w Krakowie będący, duchowieństwo Pan marszałek koronny ${ }^{71}$ ze wszytkiem niemal dworem potkali.

Dnia 26. Maii [maja] Król Jegomość wyjachawszy do Łobzowa ${ }^{72}$ i tamże wszytkie poczty oglądawszy, ruszył się z nimi przeciwko Arcyksiężnie, które Pan Koniecpolski ${ }^{73}$, poszykowawszy poczty, po prawej ręce postawił, a piechotę i mieszczany po lewej ręce. A gdy się już Arcyksiężna przybliżała ku samym namiotom [k. 2], Pan Bujanowski ${ }^{74}$ od Króla Jego Mości z karety, którą na fl. 4000 szacowano, w której szło koni 8 gniadych, tureckich, które na druga fl. 4000 szacowano, do której Arcyksiężna wsiadać nie chciała i na swej aż do namiotów przyjachała i zsiadłszy, szła $z$ matką ${ }^{75}$ do namiotu swego, gdzie się rozburdawszy i ochędożywszy, wyszły obiedwie pod vellum [baldachim], gdzie też do nich Król Jego Mość z Królową starą ${ }^{76}$ i z Królewną szwedzką ${ }^{77}$ witał, od którego rzecz czynił ksiądz podkanclerzy koronny ${ }^{78}$, a od Arcyksiężny odpowiadał biskup londeński ${ }^{79}$. Po przywitaniu rozeszli się każdy do swego namiotu, zaczem Pan Koniecpolski piechotę i poczty 2. rzędoma wprzód ruszył, za któremi Król Jego Mość ruszył się z Arcyksiężna, która zaraz $z$ namiotu wsiadła $z$ matką do karety królewskiej i tak jachali przez Kleparz do miasta samego, w którem były 3. arces triumphales [łuki triumfalne], na których różni mniszchowie i pisz-

69 Jerzy Radziwiłł (1556-1600) - biskup krakowski w latach 1591-1600.

${ }^{70}$ Klemens VIII [Ippolito Aldobrandini] (1536-1603) - papież w latach 15921605.

${ }^{71}$ Andrzej Opaliński (1540-1593) - marszałek wielki koronny w latach 15731593.

${ }^{72}$ W Łobzowie znajdował się pałac królewski pochodzacy z XIV w., przebudowany w stylu manierystycznym za panowania Stefana Batorego.

73 Aleksander Koniecpolski (zm. 1609) - poseł z województwa sieradzkiego, od 1597 r. kasztelan sieradzki, starosta żarnowiecki, wojewoda sieradzki od 1606.

${ }^{74}$ Prawdopodobnie chodzi o Jana Bojanowskiego (ok. 1549-1607) - wówczas starostę bobrujskiego i łożniczego królewskiego.

75 Maria Anna Bawarska (1551-1608) - arcyksiężna austriacka.

76 Anna Jagiellonka (1523-1596) - córka Zygmunta I Jagiellona i Bony Sforzy, żona Stefana Batorego, królowa Polski w latach 1575-1596.

77 Anna Wazówna (1568-1625) - królewna szwedzka, córka Jana III Wazy i Katarzyny Jagiellonki, siostra Zygmunta III Wazy.

78 Jan Tarnowski (1550-1605) - podkanclerzy koronny w latach 1591-1598.

79 Prawdopodobnie chodzi o Jerzego Stobacusa, biskupa Lavantu. 
czykowie różnie grali, do zamku przyjachawszy, szli prosto do kościoła, gdzie Te Deum lauda mus [Ciebie Boga wysławiamy] śpiewano, nabożeństwa swe Panu Bogu oddawszy, prowadził [k. 2v] Król Jmć Arcyksiężnę na pałacze do gmachów naznaczonych i tam mało postawszy, Król Jego Mość odszedł do swego pokoju. Potem wieczerzę dano.

Nazajutrz die [dnia] 27. Maii [maja] bywszy Król Jego Mość msze w kościele $z$ Arcyksiężna, $z$ matką, $z$ Królową starą, $z$ Królewną szwedzką. Z kościoła przyszedłszy, rozeszli się do swych pokojów. Potym szli do obiadu pod głowy ${ }^{80}$ i siedzili na majestacie Król w pośrzodku, po prawej ręce siedziała Królowa stara i Królewna, po lewej ręce siedziała Arcyskiężna, podle niej matka jej, a podle starej Arcyksiężny na rogu stołu siedział lancgraf ${ }^{81} z$ żoną swą ${ }^{82}$, nic więcej.

Dnia 28. Maii [maja] Król Jego Mość przyszedłszy z kościoła rano, zasiadł $\mathrm{w}$ radzie, gdzie biskup kujawski $\mathrm{z}$ Panem marszałkiem poselstwo $z$ siebie zdali strony traktatów u Cesarza Jegomości $^{83}$ o matrimonium [małżeństwo] $z$ Arcyksiężną. Potem posłowie Cesarza Jego Mości ${ }^{84}$, ksiądz biskup wrocławski ${ }^{85}$ i lancgraf oddali Królowi Jego Mości Arcyksiężnę Annę, winszując Błogosławieństwa Pańskiego. [k. 3]

Dnia 31. Maii [maja] rano ksiądz kardinał biskup krakowski, legat natenczas papieski, przyszedł do Króla Jego Mości, którego Król Jego Mość przez izbę wszedłszy, u wtórych drzwi potkał, gdzie trochę bywszy, ksiądz kardinał odszedł do kościoła. A zatym ubrano Króla Jego Mości jako do koronatii w kapę, w którym ubierze już w koronie sceptrum [berło] i jabłko mając w ręku, szedł do kościoła, przed którem wojewoda sędomirski ${ }^{86}$ niósł na półmisku koronę tę, którą miała być koronowana Królowa. Sceptrum [berło] niósł

80 Sala Poselska na Wawelu.

${ }^{81}$ Georg IV Ludwig (1563-1613) - landgraf von Leuchtenberg w latach 15861613.

${ }^{82}$ Marie Salome von Baden (1563-1600) - żona landgrafa Georga IV Ludwiga od $1584 \mathrm{r}$.

${ }^{83}$ Posłami do cesarza w 1592 r. byli Hieronim Rozrażewski i Albrycht Radziwiłł.

${ }^{84}$ Rudolf II Habsburg (1552-1612) - cesarz Świętego Cesarstwa Rzymskiego Narodu Niemieckiego w latach 1576-1612.

85 Andreas Jerin (1540-1596) - biskup wrocławski w latach 1585-1596.

${ }^{86}$ Jerzy Mniszech (ok. 1548-1613) - wojewoda sandomierski w latach 15891613. 
wojewoda kaliski ${ }^{87}$, jabłko wojewoda łęczicki ${ }^{88}$. Za Królem Jego Mościa drugiemi drzwiami Arcyksiężna weszła do kościoła, do swego majestatu. Stamtąd szli Król, za nim Arcyksiężna do ołtarza wielkiego, u którego kommunikowali. Tamże im ksiądz kardynał ślub dał. Potem szli na swe miejsca do majestatów, za tym msza, przy której triumphi [triumfy] się różne działy. $Z$ dział, $z$ rusznic strzelano [...] różne, Król Jego Mość na ofiarę chodził i Arcyksiężna Anna. Potem przed epistoła była koronowana od księdza biskupa kujawskiego, po której była od dwu [k. 3v] biskupów na Majestat Królewski prowadzona, tamże pospołu nabożnie modlili aż do końca mszy.

Po mszy szli oboje do zamku: Król Jego Mość do swojego pokoju i rozebrał się $z$ dalmatyki, a Królowa do swojego ze wszytkiemi Paniami i tam była, aż dano jeść. Szedł wprzód Król do stołu, potem Panowie senatorowie Królową Jej Mość przyprowadzili do stołu, tamże siedzieli w Majestacie, po prawej ręce siedział ksiądz kardynał jako poseł, naprzeciwko niego przed stołem ksiądz biskup wrocławski, a na boku lancgraf, Król Jego Mość we śrzodku, Królowa młoda podle niego, po lewej stronie Arcyksiężna stara z Królewna szwedzka. Podle lancgrafa żona jego niżej siedzieli, a $z$ obu stron sali stoły stały. Dawano na 24 misy, do kożdej po 16 półmisków. Po prawej ręce siedzieli posłowie obcy, senatorowie koronni i litewscy, inni też zacni cudzoziemcy, a po lewej ręce białegłowy cudzoziemki i nasze. Potem skoro po obiedzie szedł Król Jego Mość do swego pokoju, Królowa też do swego, a gdy wieczerza gotowa była, Król Jego Mość u Królowej Jej Mości jadł na jej pokoju, a do stołu pan[k. 4] -ny jej służyły, nie był żaden urzędnik.

Dnia 1. Iunii [czerwca] Król Jego Mość skoro po obiedzie tańcy się zabawił pod głowami godzinę w noc, a potem u Królowej wieczerzał. Panny do stołu służyli.

Dnia 2. Iunii [czerwca] rano wstawszy, Król Jego Mość mszę w kościele był, Arcyksiężna $z$ Królową młodą na pokoju mszy słuchali. Potem Królowi Jego Mości z kościoła przyszedłszy, przed obiadem oddawano upominki na pokoju Królowej młodej.

${ }^{87}$ Piotr Potulicki (zm. 1606) - wojewoda kaliski 1584-1604

88 Stanisław Miński (ok. 1561-1607) - wojewoda łęczycki w latach 1591-1607. 
Naprzód

Od Króla Jego Mości wojewoda brzeski ${ }^{89}$ Pan Graf ${ }^{90}$ i Panowie łożniczowie one nieśli. To jest:

$\operatorname{Kanak}^{91} \mathrm{z}$ wielkiemi dyjamenty i rubinami u niego pereł uryjańskich $^{92}$, które zowia „Bezary” 30. K temu krzyżyk wszytek z dyjamentami robota barzo piękna i kosztowna, który Król Jego Mość kupił za fl. 18000 .

Drugi kanak z krzyżykiem podobny temuż, tylko $z$ kamienie mniejsze i proporcja mniejsza kupiony za fl. 9000. [k. 4v]

Szkatułę kryształowa złotem i drogiemi kamieńmi oprawną, kosztuje 6000 fl., w niej łańcuch perłowy z pereł uryjańskich, każda perła po fl. 8 .

\section{Od Cesarza Jego Mości}

Ksiadz biskup wrocławski $z$ lancgrafem Kanak $z$ dyjamentami i krzyżyk szacowany na fl. 5000 .

Od Królowej Jej Mości starej

Oddawał Pan łęczicki ${ }^{93}$ łańcuch $z$ pereł uryjańskich i kanak dyjamentowy, i dwa krzyżyki, jeden rubinowy, drugi diamentowy.

\section{Od Królewny szwedzkiej}

Kanak z krzyżykiem $z$ rubinów i diamentów z jednego przypięty.

Od Księcia Palatina reńskiego ${ }^{94}$

Kanak z rubinami i z dyjamentami szacowany na fl. 3000.

${ }^{89}$ Andrzej Leszczyński (ok. 1559-1606) - wojewoda brzeski kujawski w latach 1591-1606.

90 Być może chodzi o Gustawa Brahe (1558-1615) - komornika Zygmunta III Wazy od 1587 r., podkomorzego królewskiego od 1593 r.

${ }^{91}$ Naszyjnik.

92 Perły uriańskie - określenie pereł pochodzących ze Wschodu. W epoce nowożytnej szczególnie cenne były te importowane $z$ Indii Wschodnich.

${ }_{93}$ Por. przyp. 74.

${ }^{94}$ Fryderyk IV Wittelsbach $z$ linii Pfalz-Simmern (1574-1610) - palatyn reński w latach 1574-1610. 


\section{I od Księcia saskiego ${ }^{95}$}

Kanak piękny $z$ krzyżykiem $z$ rubinami niemałemi, a drugi kanak $z$ diamentami ostremi szacowano. [k. 5]

\section{Od Księcia Bawarskiego ${ }^{96}$}

Kubeł wielki, piękną robota ze sczere<g>o złota szacowano na 3000 koron.

\section{Od Hanszpacha ${ }^{97}$}

Kanak $z$ krzyżykiem dyjamentowym $z$ rubinami, $\mathrm{k}$ temu łańcuch $z$ zawieszeniem $z$ rubinami i dyjamentami szacowany na fl. 3000.

Od arcybiskupa gnieźnieńskiego ${ }^{98}$

Dwa prawie wielkie składane roztruchany ${ }^{99}$.

Od księdza biskupa kujawskiego

Dwa kubki wielkie.

Od księdza biskupa łuckiego ${ }^{100}$

Bardzo cudny kubeł wielki.

Od księdza biskupa chełmskiego ${ }^{101}$

Kubeł jeden niemały.

Od Pana wojewody łęczyckiego

Krzyżyk dyjamentowy piękny za fl. 1000.

95 Krystian II Wettyn (1583-1611) - elektor saski w latach 1591-1611. Ze względu na młody wiek w latach 1591-1601 regencję sprawowała jego matka Zofia $z$ Hohenzollernów z księciem Fryderykiem Wilhelmem von Sachsen-Weimar.

${ }^{96}$ Wilhelm V Pobożny Wittelsbach (1548-1626) - książę Bawarii w latach 1579_ 1597.

97 Jerzy Fryderyk Hohenzollern (1539-1603) - margrabia Ansbach i Bayreuth w latach 1543-1603.

98 Stanisław Karnkowski (1520-1603) - arcybiskup gnieźnieński i prymas Królestwa w latach 1581-1603.

${ }_{99}$ Roztruchan - duży, srebrny puchar o kształcie zoomorficznym, zdobiony niekiedy kamieniami szlachetnymi. Używano go do wznoszenia toastów i jako ozdoba stołu.

100 Bernard Maciejowski (1548-1608) - biskup łucki w latach 1587-1600.

101 Stanisław Gomoliński (zm. 1604) - biskup chełmski w latach 1591-1600. 
Od Pana wojewody brzeskiego

Jeleń z koralowemi rogami. Pies u niego srebrny. [k. 5v]

Od Pana wojewody kijowskiego

Rustruchanów 7., a ósmy kubek przykryty.

Od Pana wojewody połockiego ${ }^{102}$

Rostruchany 2 .

Od Pana wojewody nowogrodzkiego ${ }^{103}$

Kubek przykryty barzo piękną robotą.

Od Pana wojnickiego ${ }^{104}$

Łańcuch $z$ smalcem i noszenie $z$ pelikanem.

Od księdza podkanclerzego

Kubek wielki $z$ białem smalcem.

Od Jegomości Pana podkanclerzego litewskiego ${ }^{105}$

Rostruchan.

Od Jegomości Pana podskarbiego litewskiego ${ }^{106}$

Rostruchan cudną robota niemały.

Od krakowian

Ośm kubków cudnych i wielkich. [k. 6]

Poznańczycy:

Miednica wielka i naliwka pozłocista.

\footnotetext{
${ }^{102}$ Mikołaj Dorohostajski (ok. 1530-1597) - wojewoda połocki w latach 1574-1597.

103 Teodor Skumin Tyszkiewicz (1533-1618) - wojewoda nowogródzki w latach 1590-1618.

104 Jan Tęczyński (zm. 1593) - kasztelan wojnicki w latach 1571-1593.

105 Gabriel Woyna (zm. 1615) - podkanclerzy litewski w latach 1589-1615.

${ }^{106}$ Dymitr Chalecki (ok. 1550-1598) - podskarbi wielki litewski w latach 1590-1598.
} 


\section{Lwowianie:}

Wielki prawie rostruchan, a w nim 1000 aug.

Gdańsczanie:

Łańcuch i noszenie $z$ dyjamentami. Miednica $z$ naliwka pozłocista. Kubek barzo wielki, szyroki i wysoki, w niem 500 portugalów. $\mathrm{K}$ temu 3. rostruchany niemałe.

\section{Ryżanie:}

Dwa prawie wielkie kubki i 100 portugalów.

Pod die [dnia] 2. Iunii [czerwca], godzina w noc race pusczano i różne ogniemi spectatula [widowiska] czyniono.

Dnia 3. Iunii [czerwca] tak się też dzień z tańcami skończył.

Dnia 4. Iunii [czerwca]. Skoro po obiedzie tańce były aż ku wieczorowi, zapalono świece, potem $\mathrm{w}$ sali, w której wyszła wieża i w pośrzód sali stanęła, z której najpierwej wyszło 62. alabardników w maszkarach, ci 2. rzędoma stanęli. [k. 6v]

Za niemi wyszło 8. śpiewaków, którzy tańcując, śpiewali \{po\} polsku, za nimi wyszło 16. muzyków, którzy też grając z nimi, długo tańcowali.

Potem wyszło 6. po męsku ubranych. Potem 6. panien, którzy $z$ niemi długo różne tańce tańcowali, trwając aż do 6. godziny w noc. Potem ta wieża odeszła, zatym się Królowa $z$ sale do swego pokoju ruszyła.

Dnia 6. Iunii [czerwca] od Król Jego Mość biskupowi wrocławskiemu i lancgrafowi tak też i innym Panom $z$ obcych krajów upominki dawano.

Tegoż dnia godzinę w noc była Królowa młoda $z$ matką do sale prowadzona. Tamże różne inwentie były prowadzone i pokazowane:

1. Jego Królewskiej Mości wyszedł wóz, na którem 4. virtutos cardinales $^{107}$ [cnoty kardynalne] i lew żywy.

2. Pana starosty krzepickiego ${ }^{108}$, skala, w której śpiewacy. [k. 7]

107 Roztropność, sprawiedliwość, umiarkowanie i męstwo.

108 Mikołaj z Podhajec Wolski (1553-1630) - starosta krzepicki w latach 1566-1630. 
\{3.\} Pana Zygmunta Myszkowskiego ${ }^{109}$ żółw, na której młodzieniec w maszkarze i wieńcu siedział.

\{4.\} Pana Stanisława Stadnickiego ${ }^{110}$ fonntana Dyany $z$ nimfami jej.

5. Panów Krasickich młodych ${ }^{111}$ murzynka wielka, przed którą szła muzyka.

6. Pan podczaszego litewskiego ${ }^{112}$ koncza, którą ciagnęli 2. delfinowie, a na niej Neptunus [Neptun] siedział, przed którym na 4. sztorciech grano.

7. Pana starosty chęcińskiego ${ }^{113}$ morze, na którem 2. syreny były i pani piękna Wysłą nazwana i innych niemało było różnych inwentii.

Potem się turniej zaczął, sam Król zaczął, z innych Wiela kruszył pikami, a potem mieczami, co wszytko trwało aż do 5. godziny w noc.

Dnia 7. Iunii [czerwca] w niedzielę w rynku były różne inwentie około szranków, które były postawione dla gonitw.

Inwentie $[\mathrm{k} .7 \mathrm{v}]$

1. Szedł wóz Jego Królewskiej Mości, na którem Hercules z Atlantem ${ }^{114}$ niebo nieśli.

2. Pana Zygmunta Myszkowskiego okręt, który ciągnęli 3. krokodyle, na którym były działa.

109 Zygmunt Gonzaga Myszkowski (ok. 1562-1615) - twórca tzw. ordynacji myszkowskiej, późniejszy marszałek wielki koronny w latach 1600-1615.

110 Stanisław Stadnicki „Diabeł łańcucki” (ok. 1551-1610) - starosta zygwulski w latach 1593-1610.

${ }^{111}$ Marcin Krasicki (1574-1631) - późniejszy kasztelan lwowski w latach 16161630, w 1592 r. był dworzaninem królewskim; i Jerzy Krasicki (zm. 1645) - późniejszy starosta doliński w latach 1605-1641 i choraży halicki w latach 16101638.

112 Krzysztof Monwid Dorohostajski (zm. 1579) - podczaszy litewski w latach 1592-1596.

113 Piotr Gonzaga Myszkowski (ok. 1560-1601) - starosta chęciński w latach $1587 / 1588-1601$.

${ }^{114} \mathrm{~W}$ architekturze postać muskularnego mężczyzny podtrzymującego ciałem elementy różne architektoniczne: balkon, taras. Atlant może również służyć jako podpora zastępujacca filar lub kolumnę. 
3. Pana podczaszego litewskiego wóz triumfalny, na którem sam w pośrzodku siedział jako Perseus ${ }^{115}$, dzierżąc w ręku na mieczu głowę medusy. Za nim siedział Mars i Pallas, a przed nim 3. Gratiæe [Gracje] ${ }^{116}$ śpiewające. Ten wóz ciagnęli 4. jednorożce, $z$ których każdego $z$ osobna nimfy wiodły. Za tem wozem 2. Gorgones Pegasum, to jest konia skrzydlatego wiodły, na którego on potym wsiadł i gonił.

4. Pana starosty chęcińskiego wóz, na którym sam $z$ niemi siedział w koronie, jako Minos sceptrum [berło] w ręku mając, ten wóz pełen był rac, który ciagnęli smoków 3., mając ogień pałający z pasczęk.

5. Tegoż Pana chęcińskiego zatem wozem szła skala, która od rac sama zgorzała, z której koń wyskoczył.

6. Pana krajczego koronnego ${ }^{117}$ była hydra o 7 . głowach, $z$ ogona się jej paliło. [k. 8]

7. Pana Stanisława Stadnickiego był sam ubrany jako gospodarz, na parepiezwackiem siedzac, za nim jachał urzędnik $z$ Barbarii, Regestrum [rejestr] majac w ręku, przed nim pług szedł ze 2. wołami, za pługiem siano i to wszytko czyniono, co gospodarstwu należy.

8. Pana starosty krzepickiego sam na plac konno przyjachał w dziwnych ubiorach, bo inwentii nie zgotowano.

9. Pana Bekieszowa ${ }^{118}$ miał łodzia, na której sam siedział, mając pełno w niej strzelby i potem obyczajem morskich zbójców uderzył na okręt Pana Myszkowskiego, tamże na się wszytkę strzelbę wypuścili i ten okręt tę łodzia pojmał.

10. Pana starosty śniatyńskiego ${ }^{119} \mathrm{z}$ Panem Sieniawskim ${ }^{120}$ przyjachał sam jako poseł perski, za któremi szli 2. wielbłądy, na których siedziało dwoje chłopiąt, mając w ręku po kubku złocistem wielkim jako dary jakie. [k. 8v]

115 Perseusz - heros w mitologii greckiej, syn Zeusa i Danae, mąż Andromedy.

116 Trzy Gracje - w mitologii rzymskiej były boginiami wdzięku, radości i piękna. Uważano je za opiekunki sztuki. Przedstawiano je jako kobiety trzymające się za ręce.

117 Piotr Opaliński (1566-1600) - krajczy koronny w latach 1588-1600.

118 Bekiesz - dworzanin królewski.

119 Mikołaj Jazłowiecki (1550-1595) - starosta śniatyński w latach 1575-1595.

${ }^{120}$ Być może chodzi o Prokopa Sieniawskiego (zm. 1596) - późniejszego marszałka nadwornego koronnego w latach 1594-1596. 
11. Pana Łaskiego ${ }^{121}$ szła galera, na której więźniowie przykuwani, wiosłami robiąc, za nia na koniach po murzyńsku jachali. Pan Łaski, starościć warszawski Pan Plaza ${ }^{122}$, Pan Woyna ${ }^{123}$, pisarz etc.

A po tych wszytkich inwentiach zaczęły się gonitwy i trwały do samego zmirzchu.

Dnia 8. Iunii [czerwca] Król Jego Mość z Królowa młoda i Arcyksiężna starą wyjachał do Niepołomic. Tegoż dnia biskup wrocławski, lancgraf i inni posłowie cudzoziemscy odjachali.

Dnia 9. Iunii [czerwca] przyjachał poseł od Panów Weneckich ${ }^{124}$, który przez dalekość drogi wesela omieszkał. Wielkie i kosztowne podarki Królowi Jego Mości przywiózł, które na fl. 12000 szacowano.

Dnia 10. Iunii [czerwca] posłów z Jędrzejowa ${ }^{125}$ Król Jego Mość słuchał, które poselstwo od nich niewdzięcznie przyjął, [k. 9] iż takich seditii pod bokiem Jego Królewskiej Mości rozburzać się ważyli. Na które poselstwo respons do sejmu odłożył, odprawiono ich 15. Iunii [czerwca].

Eodem [tego samego] die [dnia] 15. Król Jego Mość z Królową młoda, Arcyksiężnę Jej Mość starą z Krakowa na noc do Balic ${ }^{126}$ prowadził. 16. w Kurowie ${ }^{127}$ nocował. Tamże się żegnali nazajutrz 17. Arcyksiężna Jej Mość $z$ córką swą Królową Jej Mością żałosne żegnanie czyniąc w społecznem płaczu smutno się rozstały i rozjachały.

Eodem [tego samego] 18. Iunii [czerwca] do Krakowa Król Jego Mość z Królową Jej Mością młodą wrócił się.

121 Olbracht Laski (1536-1605) - wojewoda sieradzki od 1566 r.

122 Być może chodzi o Jana Płazę, starostę lubaczowskiego.

123 Maciej Woyna - pisarz litewski w 1589 roku, sekretarz Zygmunta III Wazy.

${ }^{124}$ Prawdopodobnie chodzi o Piotra Duodo (1554-1610), posła weneckiego do Rzeczypospolitej w 1592 r.

${ }^{125}$ W 1592 r. w Jędrzejowie odbył się zjazd szlachty z udziałem kanclerza i hetmana wielkiego koronnego Jana Zamoyskiego.

${ }^{126}$ Prawdopodobnie rodzina królewska noc spędziła w pałacu Firlejów w Balicach.

${ }^{127}$ Kurów - dawna wieś, obecnie dzielnica Bochni. 


\section{Bibliografia}

\section{ŹRÓDEA ARCHIWALNE}

Biblioteka Kórnicka PAN [BK PAN]

rkps 245, 309.

Biblioteka Książąt Czartoryskich w Krakowie [BCz]

rkps 351.

\section{STARODRUKI}

Biblioteka Jagiellońska w Krakowie rkps CIM QU. 5320.

Biblioteka Książąt Czartoryskich w Krakowie [BCz] 197 II, 212 I, 405 I, 456 I, 1977 II.

\section{ŹRódea DRUKOWANE}

Grabowski A., Ojczyste spominki w pismach do dziejów dawnéj Polski, diaryusze, relacye, pamiętniki i.t.p. służyć mogace do objaśnienia dziejów krajowych tudzież listy historyczne do panowania królów Jana Kazimiérza i Michała Korybuta oraz listy Jana Sobieskiego marszałka i hetmana wielkiego koronnego, Kraków 1845, t. I, s. 36-39.

Heidenstein R., Dzieje Polski od śmierci Zygmunta Augusta do roku 1594: ksiag XII, przekł. M. Gliszczyński, oprac. i wyd. J. Byliński, W. Kaczorowski, Opole 2015.

Ioachimi Bilscii Carmina Latina. Nunc primum in unum volume collecta, ed. T. Bieńkowski, Warszawa 1962.

Kronika mieszczanina krakowskiego z lat 1575-1595, wyd. H. Barycz, Kraków 1930.

Piasecki P., Kronika Pawła Piaseckiego biskupa przemyślskiego, Kraków 1870.

Radziwiłł A.S., Pamiętnik o dziejach $w$ Polsce, t. I (1632-1636), oprac. i przekł. A. Przyboś, R. Żelewski, Warszawa 1980.

The house of Vasa and the house of Austria: correspondence from the years 1587 to 1668. Pt. 1, The times of Sigismund III, 1587-1632. Vol. 1, ed. R. Skowron, Katowice 2016.

Zawadzki K., Gazety ulotne polskie i Polski dotyczace XVI-XVIII wieku. Bibliografia. t. 1, 1514-1661, Wrocław 1977.

\section{OpRacowania}

Barwicka-Makula A., Anna Austriaczka (16 sierpnia 1573 - 10 lutego 1598), [w:] Poczet władczyń Polski, red. B. Czwojdrak, Kraków 2017, s. 297-301. 
Barwicka-Makula A., Od wrogości do przyjaźni. Habsburgowie austriaccy wobec Polski w latach 1587-1592, praca doktorska pod kierunkiem dr. hab. R. Skowrona, Katowice 2013.

Barwicka-Makula A., Stół królewski podczas uroczystości weselnych Zygmunta III Wazy i Anny Austriaczki w 1592 roku, [w:] Historia naturalna jedzenia: między antykiem a XIX wiekiem. Materiały $z$ międzynarodowej konferencji naukowej zorganizowanej przez Muzeum Historyczne Miasta Gdańska i Uniwersytet Gdański dla upamiętnienia 100-lecia otwarcia Muzeum Wnętrz Mieszczańskich w Domu Uphagena w dniach 3-4 listopada 2011 roku, red. B. Możejko, Gdańsk 2012, s. 173-179.

Bochnak A., Portrety Zygmunta III i Anny Austriaczki w Muzeum Sztuki UJ, „Prace Komisji Historii Sztuki Polskiej Akademii Umiejętności” [Kraków] 1946, t. VIII, s. 327-335.

Chrościcki J.A., Barokowa architektura okazjonalna, [w:] Wiek XVII. Kontrreformacja. Barok, red. J. Pelc, Wrocław 1970, s. 229-254.

Dubas-Urwanowicz E., Wesele Jana Zamoyskiego z Gryzelda Batorówna, „Białostockie Teki Historyczne” 2011, t. IX, s. 237-251.

Estreicher K., Bibliografia polska, t. XII, Kraków 1891.

Falniowska-Gradowska A., Leitsch W., Gonitwa w maszkarach na Rynku Krakowskim (7 czerwca 1592 r.), „Rocznik Krakowski” 1985, t. LI, s. 31-56.

Filipczak-Kocur A., Wesele Zygmunta III i Anny w 1592 r. oraz koronacja królowej $w$ relacjach niemieckojęzycznych i polskich gazet ulotnych, [w:] Wesela, chrzciny $i$ pogrzeby $w$ XVI-XVIII wieku. Kultura życia $i$ śmierci, red. H. Suchojad, Warszawa 2001, s. 91-104.

Grzebień L., Sokołowski (Socolovius) Stanisław h. Gozdawa (1537-1593), [w:] Polski słownik biograficzny, t. XL, Warszawa-Kraków 2000-2001, s. 183-189.

Kadzik D., Utrzymanie królewskiej teściowej: wizyta Marii Bawarskiej podczas wesela Zygmunta III Wazy z Anna Habsburg (23 maja - 16 czerwca 1592 r.), Kraków 2017.

Keller K., Erzherzogin Maria von Innerösterreich (1551-1608). Zwischen Habsburg und Wittelsbach, Wien-Köln-Weimar 2012.

Kutrzeba S., Koronacje królów i królowych w Polsce, Warszawa 1918.

Kutrzeba S., Ordo coronandi Regis Poloniae, „Archiwum Komisji Historycznej” [Kraków] 1909-1913, t. XI, s. 133-216.

Lepszy K., Anna Austriaczka, [w:] Polski słownik biograficzny, t. I, Kraków 1935, s. $132-133$.

Lepszy K., Rzeczpospolita Polska $w$ dobie Sejmu Inkwizycyjnego (1589-1592), Kraków 1939.

Leszczyńska A., O muzyce $w$ obrzędach koronacyjnych królów polskich, „Polski Rocznik Muzykologiczny" 2015, t. XIII, s. 81-98.

Malicki M., Joachima Bielskiego nieznane polskie „Epithalamion” na ślub Zygmunta III i Anny Austriaczki, „Biuletyn Biblioteki Jagiellońskiej” [Kraków] 1994, t. XLIV, nr 1-2, s. 119-129.

Nowak-Dłużewski J., Okolicznościowa poezja polityczna $w$ Polsce. Zygmunt III, Warszawa 1971. 
Pirożyński J., Krakowskie uroczystości państwowe i dworskie $w$ drugiej połowie XVI wieku $w$ świetle ówczesnych prototypów prasowych, [w:] Theatrum ceremoniale na dworze książąt i królów polskich, red. M. Markiewicz, R. Skowron, Kraków 1999, s. 193-205.

Podhorodecki L., Wazowie w Polsce, Warszawa 1985.

Polscy dyplomaci w Wiedniu 1515-2015, red. B. Dybaś, Wiedeń 2015.

Rokosz M., "Forum Polonorum et Via Regia”. Rynek krakowski i Droga Królewska scena wydarzeń państwowych, religijnych, narodowych i społecznych 12572010, [w:] Rynek krakowski odkryty na nowo, red. E. Firlet, Kraków 2014, s. 405-610.

Rożek M., Polskie koronacje i korony, Kraków 1987.

Rożek M., Uroczystości w barokowym Krakowie, Kraków 1976.

Rudzki E., Polskie królowe. Żony królów elekcyjnych II, Warszawa 1987.

Ruszczyc J., Portrety Zygmunta III i jego rodziny, „Rocznik Muzeum Narodowego w Warszawie" [Warszawa] 1969, t. XIII, cz. 1, s. 151-264.

Siarczyński F., Obraz wieku panowania Zygmunta III króla polskiego i szwedzkiego czyli obraz stanu, narodu i kraju..., Poznań 1843.

Suchojad J., Wesela, chrzciny i pogrzeby w XVI-XVIII wieku. Kultura życia i śmierci, Warszawa 2001.

Szweykowska A., Widowiska baletowe na dworze Zygmunta III (4 czerwca 1592, 13 oraz 18 grudnia 1605), „Muzyka” 1966, t. XI, nr 1 (40), s. 27-36.

Targosz K., Królewskie uroczystości weselne w Krakowie i na Wawelu w 15121605, Kraków 2007.

Targosz K., Oprawa artystyczno-ideowa wjazdów weselnych trzech sióstr Habsburżanek (Kraków 1592 i 1605, Florencja 1608), [w:] Theatrum ceremoniale na dworze książąt i królów polskich, red. M. Markiewicz, R. Skowron, Kraków 1999, s. 207-244.

Vocelka K., Habsburgische Hochzeiten 1550-1600. Kulturgeschichtliche Studien zum manieristischen Repräsentationsfest, Wien 1976.

Windakiewicz S., Dzieje Wawelu, Kraków 1925.

Wisner H., Dyplomacja polska w latach 1572-1648, [w:] Historia dyplomacji polskiej, t. II (1572-1795), red. Z. Wójcik, Warszawa 1982, s. 5-161.

Wisner H., Zygmunt III Waza, Wrocław 1991.

Zawadzki K., Poczatki prasy polskiej. Gazety ulotne i seryjne XVI-XVIII wieku, Warszawa 2002. 